\title{
The Green Line
}

\section{Potency, Absurdity, and Disruption of Dichotomy in Francis Alÿs's Intervention in Jerusalem}

\author{
Mette Gieskes
}

Jerusalem is one of the places where the personal concerns of artist Francis Alÿs (Antwerp, 1959) have coincided with local circumstances. Like many other artists in today's age of globalization and biennial culture, Alÿs travels the world like a nomad, creating his artworks - or 'interventions', as he calls them - in response to the places he visits, often situations of societal and economic crisis or political impasse. Not infrequently, his interventions, in the artist's own words, 'hit a nerve' in the local community and beyond, usually when his own preoccupations 'meet' the situation he encounters with a fruitful 'clash'. The confrontation between Alÿs's narrative and Jerusalem, which took place on the fourth and fifth of June 2004, received the title The Green Line: Sometimes doing something poetic can become political, and sometimes doing something political can become poetic. For this piece, which has also been referred to as Walk through Jerusalem, Alÿs walked through what he has identified as the archetypal city of conflict with a pierced can of green paint in his hand, creating a line that traced his journey (Fig. 2.1). ${ }^{2}$ The artist's route roughly followed the section within Jerusalem of the armistice demarcation line that has separated the Israeli and Palestinian communities since the end of Israel's War of Independence in 1948: a contested border that was internationally ratified under UN supervision in 1949, and has therefore been dubbed 'the 1949 armistice line', but lost official boundary status in 1967 (Fig. 2.2).

Both concept and structure of The Green Line are markedly simple, yet the work evokes a complex network of associations, regarding the history, present, and future of Jerusalem as well as themes prevalent in much contemporary art, including Alÿs's own work. The work first and foremost inspires reflection on the contemporary status of the 1949 armistice line Alÿs partially traced $5^{6}$ years after its institution in 1948. The line has been viewed both as an undesirable, arbitrary source of conflict and division and - contrarily - as a relatively

1 From: Francis Alÿs, A Story of Deception 2010, p. 35 .

2 Francis Alÿs, A Story of Deception 2010, p. 37.

(C) METtE GIESKES, 2014 | DOI 10.1163/9789004270855_004

This is an open access chapter distributed under the terms of the Creative Commons AttributionNoncommercial 3.o Unported (CC-BY-NC 3.o) License. 


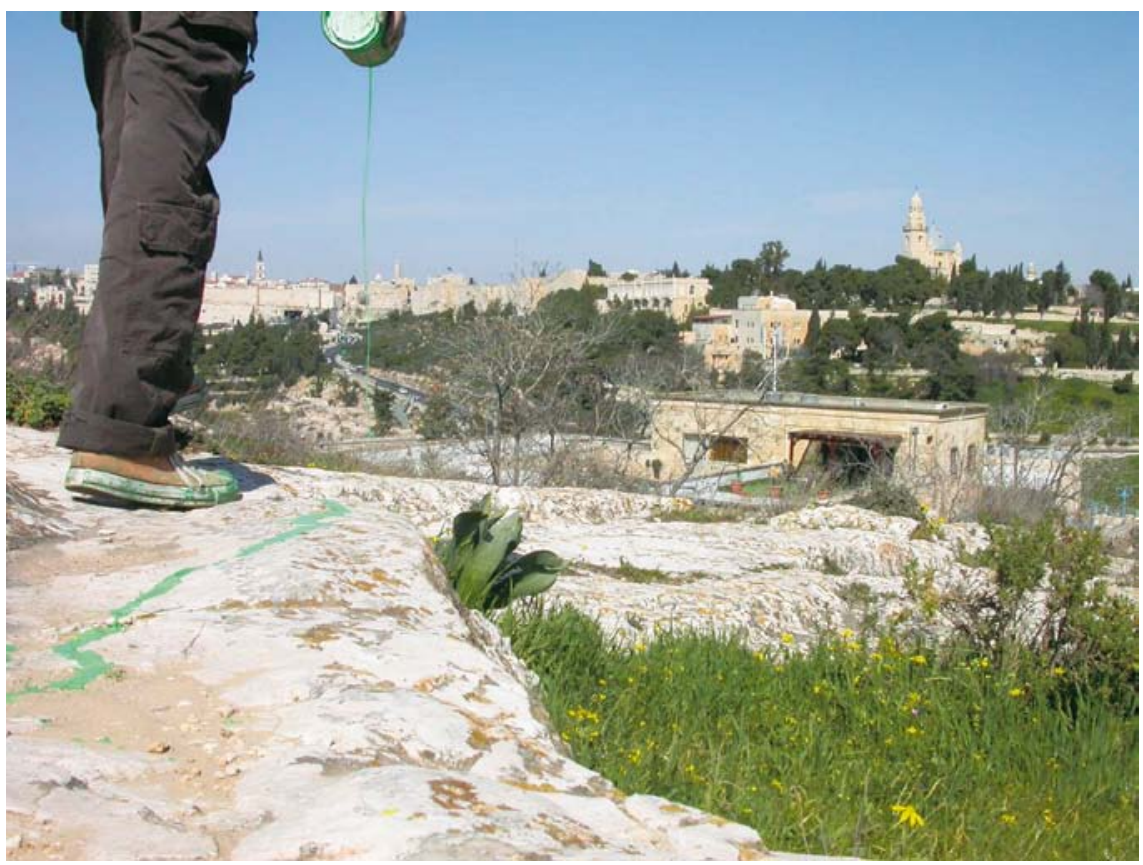

FIGURE 2.1

Francis Alÿs, The Green Line, Jerusalem 2004, Video documentation of an action. COURTESY DAVID ZWIRNER, NEW YORK/LONDON.

flexible and unimposing, yet, according to some, much needed boundary between Palestinians and Israelis; one that is much preferable to the relentless, mammoth separation walls built under the aegis of Ariel Sharon some 55 years later; one that may contain the only promise of future peace. Besides rekindling the memory of what can be seen as the source of the separation of Israelis and Palestinians and triggering consideration of the contested past and prospects of Jerusalem, The Green Line also relates to the artist's own oeuvre, which he conceives of as a narrative that is constructed by the episodes that are his works. $^{3}$

Many of the chapters of Alÿs's fiction, like the episode of The Green Line, are set in a particular site which the artist, so to speak, has imported into his fiction, and zoom in on the specific circumstances of that site. ${ }^{4}$ Yet, in spite of the site-specificity and uniqueness of each of the episodes, several themes can be detected that since the 199os have recurred in the multiple episodes that make

3 Francis Alÿs, A Story of Deception 2010, pp. 19-20, 35. Cf. Alÿs and Lambrechts 2013 (accessed November 2013).

4 Francis Alÿs, A Story of Deception 2010, p. 36. 


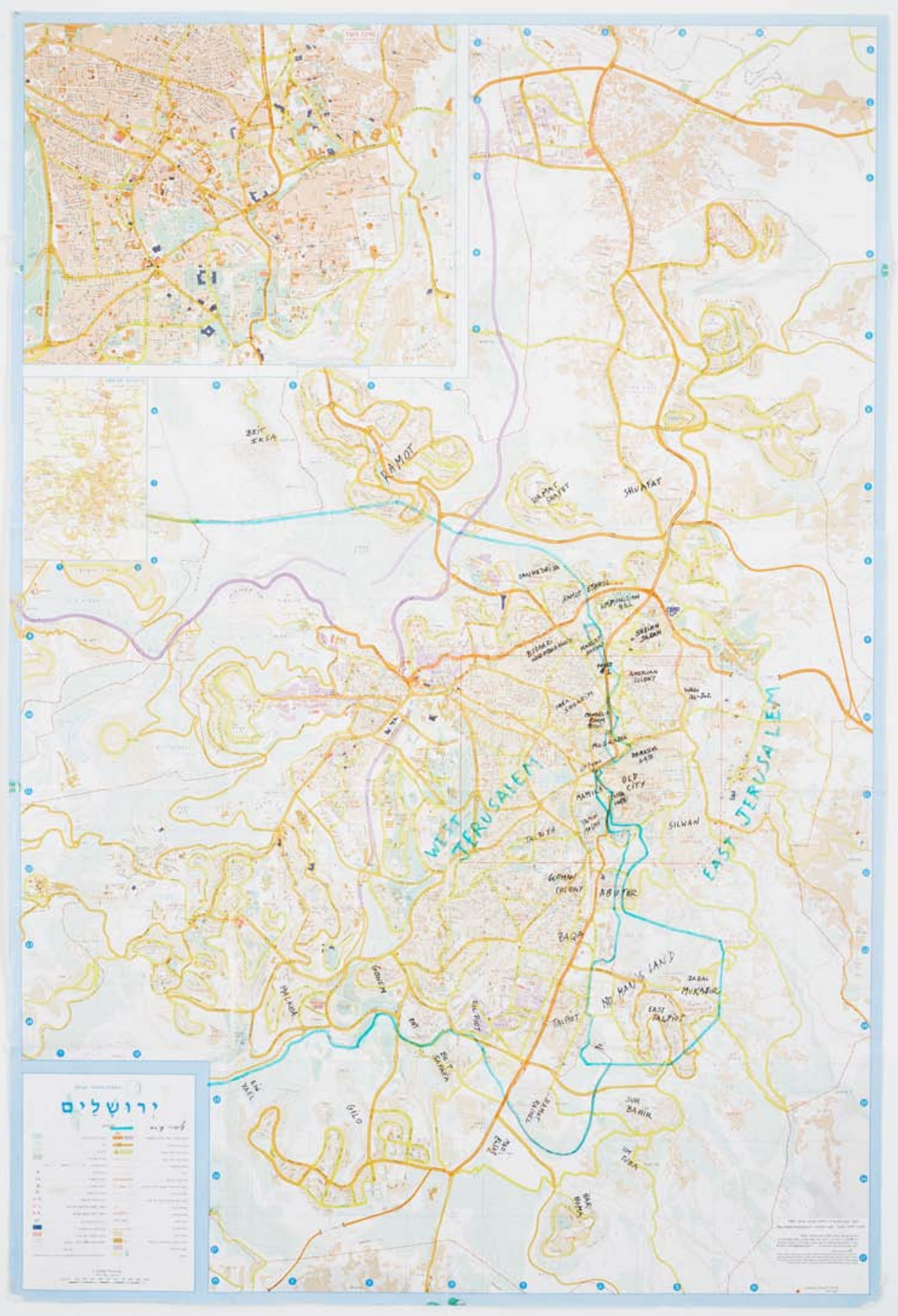

FIGURE 2.2 Francis Alÿs, The Green Line, Jerusalem 2004, Ephemera. COURTESY DAVID ZWIRNER, NEW YORK/LONDON. 
up the weaving of Alÿs's personal narrative, including the episode set in Jerusalem. Among these themes are the relation between art and politics, social practices and structures that acquire sculptural shape, Western modern hegemonic structures of control as well as informal practices that exist in spite of the predominance of such structures (e.g. bartering, drug trafficking, and artist's strolls), and, more specifically, the repercussions of border regulations. Other themes recurring in Alÿs's narrative, not so much manifest in The Green Line, are the deceptive myth of progress that defines the capitalist project, the overvaluation of efficiency, and informal labor. From the beginning, Alÿs's narrative has moreover given a central place to the Greek notion of the polis as a place of conflicts 'whence the materials to create fictions, art and urban myths are extracted'. ${ }^{5}$ It seems that Alÿs's journey through sites that offer new material and dimensions to his narrative - often sites that show the pitfalls of modern systems of control - was bound to lead him to Jerusalem, the city Israeli and Palestinians both see as the political and administrative center of their respective territories. It had previously taken him to places like Mexico City, Tijuana, and Lima, and would later lead him to Havana and Kabul.

This paper will consider how The Green Line fits into the narrative of Alÿs's oeuvre and through which mechanisms it was able to hit a nerve locally as well as globally. Did the work, which seems to call attention to the artificiality and absurdity of borders, emerge from a hope that art can provide a way out of impasse, that art is capable of affecting politics, as the subtitle suggests? Given that in Alÿs's works, structure and shape tend to be analogues for social situations and practices, what can be made of the simple shape of the line? Having its origins in a can of paint, held by an artist, the line Alÿs left behind during his walk through Jerusalem seems to refer to one of the most basic elements of art - the artist's mark - yet here this essential feature of art appears in a public site of political conflict. Like its location, the line's horizontality and temporality have implications as well. In all its simplicity and specificity, this line seems to be pregnant with meaning. This paper will discuss the green line in Alÿs's Walk through Jerusalem as the locus where various kinds of dialectics meet and are dissolved, incarnating both simplicity and complexity, separation and linkage, inflexibility and fluidity, arbitrariness and purpose, irony and seriousness, and art and politics. At the end, discussions of the various types of dialectics embodied in Alÿs's protean line will bring out the paradox in Alÿs's use of a line, the most concrete manifestation of the idea of borders, to defy and contest boundaries, including also those between the local and the global, representation and abstraction, life and art, and conflict and solution.

5 Francis Alÿs, A Story of Deception 2010, p. 51. 


\section{The Green Line: Source of Conflict and Conciliation}

Alÿs's action in Jerusalem was recorded on video by filmmaker Julien Devaux, while the artist walked and traced a line of about 24 kilometers through various neighborhoods, roads, and uninhabited lots of land, walking past several barriers and security control posts that restrict the movement of the city's inhabitants, primarily Palestinians. ${ }^{6}$ At various intervals, the artist stopped to refill the can in order to ensure that the line was continuous, using a total of $5^{8}$ liters of green vinyl paint. ${ }^{7}$ The ensuing video is engineered in such a way that the refilling is not shown. What is remarkable about the footage on the video is that few bystanders react to the artist's activity, including the guards at the security check points, possibly because the presence of the camera set Alÿs's action off as an extraordinary, singular event with a destination beyond the immediate surroundings, paradoxically neutralizing its immediate effects.

Although the video survived as a document of Alÿs's walk, it should also be seen as an integral part of the work, which was first put on view at the Israel Museum in Jerusalem in 2005, and in 2007 at the David Zwirner Gallery in New York. In both Jerusalem and New York, it was shown as part of an exhibition that carried the name of the subtitle of the work: Sometimes doing something poetic can become political, and sometimes doing something political can become poetic, a qualified yet still hopeful statement that can be seen as the leading maxim of many of Alÿs's works. In the David Zwirner gallery, not only a projection of the film was shown, but also archival material about the Green Line, paraphernalia, sculptures by the name of camguns - hybrids between camera's and machine guns - and paintings of various places in and around Jerusalem, such as Jerusalem E., Baqe, Bazra and Untitled (2004), which the artist created while he was working on The Green Line (Fig. 2.3). ${ }^{8}$ Eleven interviews the artist conducted in October 2004 with various distinguished people - mostly Israeli and Palestinians - while they watched an excerpt of the recorded walk were also made available in the exhibition space, on computers with headphones. These interviews, some of which can now be accessed through the artist's website, gave visitors to the gallery a sense of the variety of

6 Public access: www.francisalys.com (accessed October 2013).

7 Alÿs 2007, s.p.

8 See: 'Francis Alÿs', Art|40|Basel. David Zwirner 2009, pp. 12-13, as well as images of the installation and of individual works on view in the exhibition at David Zwirner in 2007: http://www. davidzwirner.com/exhibition/sometimes-doing-something-poetic-can-become-politicaland-sometimes-doing-something-political-can-become-poetic/?slide=1 (accessed October 2013). It is not uncommon for Alÿs to display drawings, objects, paintings, diagrams, photos, letters, and other ephemera as part of the installations of his works. See: Francis Alÿs, A Story of Deception 2010, pp. 12-13. 


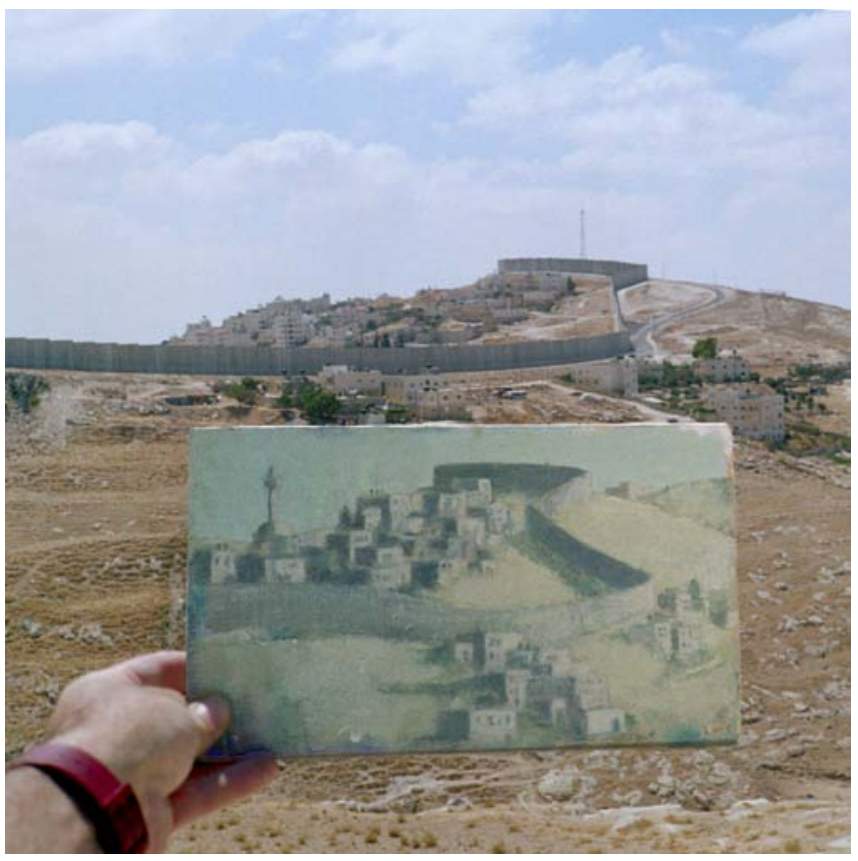

FIGURE 2.3 Francis Alÿs, View of Aboudis, Jerusalem, June 2004, Photograph featuring Untitled (2004). COURTESY DAVID ZWIRNER, NEW YORK/LONDON.

views on the situation in the Middle East, particularly with regard to the status of the 1949 armistice line, and on the power and limits of art in such situations of conflict, though most of the interviewees seem to have been partial to the Palestinians. ${ }^{9}$

What gave Alÿs's walk through Jerusalem an extra charge and provoked much commentary was of course the fact that his route was determined by the Green Line that Lt Colonel Moshe Dayan, military commander of the Israeli forces in the region of Jerusalem towards the end of Israel's 1948-49 War of Independence, had drawn with green wax pencil on a map by the scale of 1:25,000 on the 3oth of November, 1948, the year of the end of the British/United Nations Mandate of Palestine and the proclamation of the State of Israel. ${ }^{10}$

$9 \quad$ Alÿs interviewed activist Ruben Aberjil, historian Albert Agazarian, Knesset deputy and daughter of Moshe Dayan, Yael Dayan, art historian Jean Fisher, journalist Amira Hass, architect Nazmi Jobeh, publisher Yael Lerer, filmmaker and critic of Israeli politics Eyal Sivan, activist Michel Warschawski, and architect and critic Eyal Weizman. See: http:// francisalys.com/greenline/ (accessed October 2013).

10 Most sources on Alys mention a scale of 1:20,000, probably based on Meron Benvenisti, whose book Alÿs himself cites in the video. See: Benvenisti 1996, p. 57. Newman, however, 
The line was approximately 310 kilometers in length, starting at the northern section of the Jordan Valley and ending in the Dead Sea at the median line between Israel and Jordan, officially separating Israel from the West Bank, from 1948 until $1967 .{ }^{11}$ Dayan had plotted the line on the basis of the position of the Israeli and Arabic armies at the time of the armistice that marked the end of the Arab-Israeli war, to mark the land that was to be controlled by Israel. Lt Colonel Abdullah al-Tal, the Jordanian commander representing the Arab forces in the Jerusalem region, marked the boundaries of the areas under Jordan control with red pencil. The two lines converged in most places, but failed to do so at some sites, areas that were to become demilitarized buffer zones, widely known as 'no-man's land.' 22 The line was hence, as is not uncommon with borders, a product of both conflict and attempts at resolution and reconciliation.

The line settled upon in 1948 was, with some adjustments, internationally recognized in 1949 as the provisional eastern border of Israel in the Rhodes Armistice Agreements, also signed by the neighboring countries Egypt, Lebanon, Jordan, and Syria. ${ }^{13}$ David Newman gives an overview of the changes made in the 1949 agreements, which slightly altered the course of the demarcation line of 1948. Many of the changes were determined by Israel's desire to maintain control over main roads and railways and, less, by the needs of the local population. The 1949 armistice line was, as a result, more curved in some places than the line drawn by Dayan in $1948 .{ }^{14}$ Within Jerusalem, the most southern point of the line is near Ramat Rachel and its most northern point is in the proximity of Givat HaMivtar. According to Meron Benvenisti, whose 1996 book City of Stone: The Hidden History of Jerusalem Alÿs excerpted in his

states that the scale was 1:25,000. Newman 1995, p. 8. Newman writes that the line on the map was drawn with colored pencil, called green because it was printed in green on Israeli maps. See: Newman 1995, p. 8. Newman bases his account on Moshe Brawer's The Boundaries of Eretz Israel, Tel Aviv: Yavneh 1988, written in Hebrew. The only copy of the map was apparently stored in a safe deposit box at the UN observers' headquarters at Armon HaNatziv. Alÿs used a map from 2003 published by the Survey of Israel Institute. Alÿs 2007, s.p.

11 Newman 1995, pp. 3, 8. From 1950 until 1988, residents of the West Bank were Jordanian citizens. Hanson Bourke, p. 18. Jordan did not give up its rights to the West Bank when Israel conquered it in 1967. In 1988, however, Jordan recognized the state of Palestine when Palestines declared independence.

Eg. the area between the villages Katana and Budrus, just north of Jerusalem. Newman 1995, p. 8.

13 Newman 1995, pp. 4-9.

14 Newman 1995, p. 9. 
video, the width of the actual, coarse pencil marks, approximately three to four millimeters on the map, in reality covered an area of 60 to 80 meters. Benvenisti writes: "These vast buffer zones quickly became empty "no man's lands" prohibited to both sides, scarring the heart of Jerusalem.15 Newman has also remarked that the area along the boundary line, which was situated in the city core, remained undeveloped, especially the no man's land that between 1948 and 1967 was the only border crossing along the 310-kilometer Green Line, with a width that at places reached hundreds of meters. ${ }^{16}$ After 1980 , when Israel officially declared Jerusalem as physically united, parks and residential areas were established in previous frontier zones, but much land is still undeveloped. ${ }^{17}$ Alÿs's video documents this uncultivated land: a viewer unaware of the location of the artist's walk may well suspect at times that Alÿs was walking through the countryside rather than through a legendary city.

As the armistice line was not officially marked on the actual land, partly because it was not meant to be a permanent border but rather a temporary boundary separating two communities into ethnically homogeneous territories, it did not have as obvious an effect as it might have had under other circumstances, but the experience of division, both physically and mentally, has been real since 1948. Newman has observed that the line remained 'strongly imprinted on the mental images of Israelis, Palestinians, and the International Community as constituting the territorial demarcator between two people and their respective territories'. ${ }^{18}$ As the years went by, both Israelis and Jordanians built wire fences and patrol roads, and mined border areas along and near the Green Line to mark the line and to enhance security. ${ }^{19}$ In 1953, Border Guards were established. ${ }^{20}$ People living along the line on both sides have lived in fear of aggression. Even if the Green Line has no longer had any real political bearing since 1967, when Israel expanded its territory during the Six-Day War and has since then blurred and shifted the line through building activities and expansion drift, the division of 1948 is still manifested in Jerusalem's layout and

15 Benvenisti 1996, pp. 56-57. It is difficult to verify Benvenisti's account. Other sources indicate that the pen lines covered 1 millimeter on the map (Newman 1995, p. 8), while yet others speak of 2 millimeters, which would amount to 200 meters in reality. See, for instance: http://www.jewishpress.com/sections/travel/jerusalem-walking-tour-alongpart-of-the-1948-armistice-line/2012/o9/28/ (accessed October 2013).

$16 \quad$ Newman 1995, p. 40.

$17 \quad$ Newman 1995, p. 42.

$18 \quad$ Newman 1995, p. 2.

19 Newman 1995, p. 9.

$20 \quad$ Newman 1995, p. 11. 
its inhabitants' daily lives, continuing to separate the East from the West. ${ }^{21}$ It still marks an internal boundary, between the land administered by Israel and the surrounding territories that Israel occupied following the Six-Day War of 1967: the West Bank and the Gaza strip. ${ }^{22}$ The de facto preservation of an officially revoked boundary has been deliberately secured by Israel in various ways. As Newman has pointed out, Israel has, for instance, minimized economic contact between the West Bank and land west of the former Green Line, protecting the Israeli economy by preventing cheap products from crossing the line. He describes this Israeli strategy as a symptom of the paradox that Israel opened the boundary yet at the same time inhibited movement of goods and people across the line, therewith in effect perpetuating the line and closing the boundary that was officially open. ${ }^{23}$

Although the Green Line that Dayan had drawn was contested since its inception, after 1967 the question arose if Israel should not again recede to the 1948 line, which may have been all but ideal for Palestinians, but was much more favorable for them than the situation that arose in 1967, when Israel started to disregard borders, confiscating land that according to the 1949 negotiations did not belong to it, and - after 1967 - founding settlements in the West Bank and constructing various types of infrastructure. ${ }^{24}$ After the 1967 War, Israel actually instituted a law annexing East Jerusalem to its own territory. Since then, highly segregated Jewish residential neighborhoods have been founded in the eastern part of the city, located in such a way that a potential future repartitioning of Jerusalem into a Jewish West and a Palestinian East has become close to impossible, unless the settlers are evacuated. ${ }^{25}$ Eyal Weizman, who has written about the 'spatial politics' of Jerusalem, has pointed out that the line is shown on most Palestinian and international maps, but on few official Israeli ones, suggesting that Israel would happily erase the memory of the once official status of the line. ${ }^{26}$ Some argue that the Green Line should again

21 See: http://www.sayarch.com/introduction-to- $\% \mathrm{E}_{2} \% 80 \% 9$ Cresolution-planning $\% \mathrm{E} 2 \%$ 80\%9D-2/1020/ (accessed October 2010). See also: Newman 1995, pp. 1-3.

Hanson Bourke, pp. 17-20. The Golan Heights is also internationally considered occupied territory, but in 1981 the Knesset extended Israeli administration, jurisdiction, and legislation to the area.

23 Newman 1995, p. 13.

24 Newman 1995, p. 14.

25 Newman 1995, pp. 40-41.

26 Weizman in Francis Alÿs, A Story of Deception 2010, p. 175. Weizman is not alone in pointing out that Israel benefits from covering up the history of the green line. Peace Now, an activist non-governmental organization that advocates a two-state solution to the conflict between Israel and Palestinians, has argued that the so-called 'infitada bypass' roads 
serve as a starting point of negotiations, as it was in the early 1990 s. $^{27}$ Fatah, for instance, sees the line as a potential future border of a Palestinian state, but most members of Hamas are not open to this. The paradoxical situation has arisen that a line that once propelled and in memory still embodies conflict, may at the same time offer a solution that would not be perfect, but that would at least end the current impasse.

\section{Porous Lines, Intrusive Walls}

The question arises whether Alÿs's action, by reinserting the Green Line in Jerusalem, a city of division that in 1980 was, however, declared by the Knesset the 'complete and united' capital of Israel, advocated a return to the situation before 1967. The appealing unobtrusiveness, relative fluidity and even horizontality of Alÿs's line could indeed be interpreted as expressing a positive nod to what are often called the 'pre-1967 borders', which were much more flexible, immaterial, and abstract, than the literally and physically segregating, concrete and dominantly vertical security barriers that Israel has constructed in various cities since 2002, following attacks of Arabic suicide terrorists during the second Intifada. ${ }^{28}$ These separation barriers, often dubbed 'apartheid walls' by Palestinians, are to reach a length of more than 420 miles long, consisting of concrete walls as tall as 26 feet within areas of Jerusalem. Its locations are controversial, to say the least: as estimated in 2011, after completion of the barrier, which departs in many places from the route of the Green Line, 9.5\% of the West Bank is estimated to be situated on the western side, $85 \%$ of the barrier being located in the West Bank. ${ }^{29}$ Such massive separation walls appear on

Israel has built to connect the settlements to the main Israeli land, all in the name of increase of security for Israel, were meant 'to create for their users the illusion that the Green Line has disappeared and that there is no Arab population in the area. See: http:// www.fmep.org/reports/archive/vol.-5/no--3/new-roads-create-an-asphalt-revolution (accessed October 2010). Cf. Newman 1995, p. 14. Hanson Bourke argues that most Palestinian maps do not show the Green Line either. Hanson Bourke, p. 47.

27 Newman 1995, p. 1. Newman's Boundaries in Flux: The 'Green Line' Boundary between Israel and the West Bank - Past, Present and Future, is a synthesizing study of the history and future of the Green Line that is clearly predicated on the idea that the Green Line should play a role in future negotations. In 1995, Political geographer Newman was exploring various alternatives to a two-state solution of the Israel-Palestine problem.

28 Hanson Bourke, pp. 46, 64.

29 See: 'The Separation Barrier', http://www.btselem.org/separation_barrier, the website of the Israeli Information Center for Human Rights in the Occupied Territories (accessed 


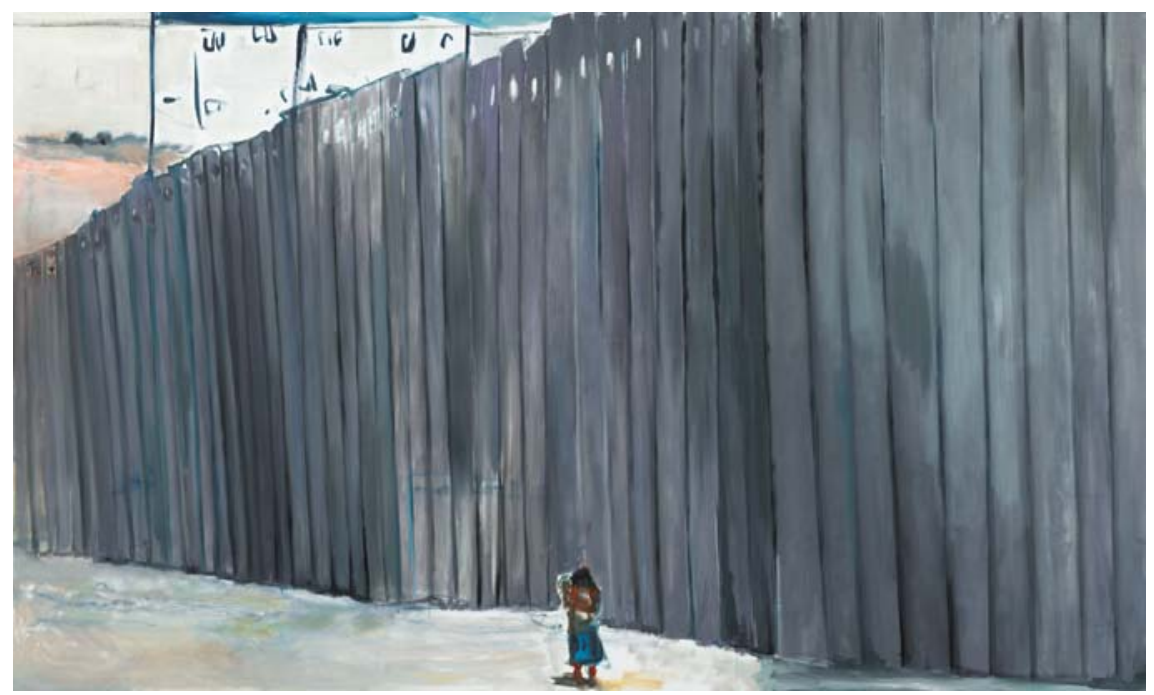

FIGURE 2.4 Marlene Dumas, Figure in a Landscape, 2010 , oil on canvas, $180 \times 300 \mathrm{~cm}$. COURTESY THE ARTIST AND DAVID ZWIRNER, NEW YORK/LONDON.

some of the paintings Alÿs made in Jerusalem while working on The Green Line and are also the subject of a series of paintings of Marlene Dumas, which were shown at the David Zwirner Gallery in 2010 in the exhibition Against the Wall (Fig. 2.4).

When comparing the uncompromising, almost threatening walls that appear in these paintings to Alÿs's green line, the latter appears especially nonintrusive, emphasizing the merits of the status the Green Line had had prior to 1967: comparatively few gates or walls were erected on the actual land to mark the provisional armistice line, as a result of which the boundary was relatively easily passed and adjusted, even if the 1949 line did lead to economic and settlement dislocation, cut off people - mainly Palestinians - from fertile fields, houses, and places of employment, and severed eighty villages from parts of their land. ${ }^{30}$ Alÿs's paintings Baqe and Bazra (2004), and - more emphatically so - Dumas's Figure in a Landscape (2010) and The Wall (2009), on the other hand present the depicted walls as vertical, imposing structures that obstruct both view and movement. ${ }^{31}$ Like Alÿs's individual works, which often respond to a particular socio-political situation yet are intrinsically woven into the fabric of the artist's narrative, Dumas's paintings from the Against the Wall series

October 2013). Cf. Hanson Bourke, p. 64.

$30 \quad$ Newman 1995, pp. 9-12; Hanson Bourke, pp. 43, 62-64.

$3^{1} \quad$ See: Against the Wall. Marlene Dumas 2010. 
correspond to the personal narrative of the South African-Dutch artist, whose work is rooted in the experience of Apartheid. Many of Dumas's paintings concern segregation, oppression, and humanity's failure to coexist. Her paintings from the above-named series are the first in her oeuvre that provide a criticism of this failure by means of a representation of architecture: oppressive constructions that determine and restrict people's lives in a very literal way. ${ }^{32}$ The Wall, based on a newspaper photograph, depicts a group of Orthodox Jewish men in front of a wall that could be interpreted as the Wailing Wall in Jerusalem but which is actually an Israeli security fence near Bethlehem. Viewers of Wall Wailing and Wall Weeping, two other paintings from the Against the Wall series, are also likely to interpret the depicted walls as the Wailing Wall, but the people pressed against the wall actually depict Palestinians who in 1967 were searched by Israelis in a raid in Jerusalem. ${ }^{33}$

In considering the disjunction between the transience, horizontality, and fragility of the Green Line on the one hand and the permanence, verticality, and massiveness of the security wall on the other, it is useful to refer to a small publication of the Henry Moore Institute in Leeds of 2008 that accompanied the exhibition The Object Quality of the Problem (On the Space of Palestine/Israel), which reflects on the Palestine/Israel conflict in spatial terms. ${ }^{34}$ In this catalogue, which also includes a short entry on Alÿs's The Green Line, writer Adania Shibli explains that she is unwilling to view Palestine as a 'territory', a term that to her 'suggests borders'. While 'the occupier/colonizer' has turned the land into territory by 'cutting' space that was once unmarked and 'continuous', Palestinians still attempt to experience the space as a porous 'space of flows.' ${ }^{35}$ In another contribution to the same catalogue, Eyal Weizman's 'Politics of Verticality' - a section from Hollow Land - Israel's Architecture of Occupation (2007) - this space of flows is characterized as 'indivisible territory'. ${ }^{36}$ Weizman argues, following Ron Pundak, one of the main masterminds of the

32 See: 'Against the Wall" by Marlene Dumas opens at Serralves Museum' 2010.

33 'Against the Wall" by Marlene Dumas opens at Serralves Museum' 2010.

34 The project The Object Quality of the Problem (On the Space of Palestine/Israel) started by asking the question of whether sculptural thinking can help 'understand another place, and other spatial experiences, as lived elsewhere, in our own time'. The Object Quality of the Problem 2008, p. 8.

The Object Quality of the Problem 2008, p. 10. Since the First Intifada (1987-1991/1993), regulations for Palestinians from the Occupied Territories like the West Bank traveling to Israel for (temporary) employment have been much stricter than before: workers are issued identity cards that have to be shown at check posts and road blocks established along what used to be the Green Line. Newman 1995, p. 14.

36 The Object Quality of the Problem 2008, pp. 41-45; Weizman 2007, pp. 12-16. Cf. Weizman in: Francis Alÿs, A Story of Deception 2010, pp. 175-77. 
Oslo Process of 1993, that the only feasible way to divide this single, indivisible territory is a three-dimensional matrix of roads and tunnels. Weizman mentions that President Bill Clinton's 2000 plan for the partitioning of Jerusalem proposed that all sections of Jerusalem occupied by Jews were to become Israeli, while all sections inhabited by Palestinians were to constitute the Palestinian State. Sixty-four kilometers of walls 'would have fragmented the city into two archipelago systems along national lines. Forty bridges and tunnels would have accordingly woven together these isolated neighborhood-enclaves'. ${ }^{37}$ Various buildings in the Old City would have been split along vertical lines between Israelis and Palestinians, with the lower floors occupied by Jews and the upper floors inhabited by Muslims. Although this three-dimensional plan may seem doomed for failure, it reflected a real 'political space', desperately struggling to 'separate the inseparable'. ${ }^{38}$ It moreover was in fact not much more than an extension of the actual situation: Weizman points out that Palestinian militants have been circumventing Israeli barriers in three dimensions, digging tunnels and launching rockets through the air, while the existing Israeli infrastructure, with its elevated bypass roads, viaducts, and tunnels, has also already taken three-dimensional form.

\section{Artificial Borders and Absurdity}

Although considerations of 'technologies of domination'39 like solid walls may make an interpretation of Alÿs's appealingly non-intrusive and modest line as an attempt to point out the benefits of the 1949 armistice line plausible, various other qualities of the work speak against it: the line's emphatic ephemerality could also be interpreted as an expression of partiality to disappearance, and concomitantly a preference for unification over the segregation that would persist with an official reinstitution of the Green Line. Moreover, Alÿs's line, which - as noted above - cuts through neighborhoods, not taking the slightest notice of the daily routines of inhabitants of Jerusalem, seems to be a parody of the callous way in which Dayan had cut a line on the surface of the map, that abstracted representation, not considering the way the actual space was used by either Israelis or Palestinians. Even if, as noted earlier, the 1949 lines were somewhat adjusted to the reality of the lives of the land's inhabitants, the armistice agreements of 1949, Brawer and Newman have observed, still discounted the 'physical and human geographical features' along the full length of the

37 The Object Quality of the Problem 2008, pp. 41-42.

38 Weizman in: The Object Quality of the Problem 2008, p. 43.

39 Weizman in: The Object Quality of the Problem 2008, p. 44. 
boundary, also ignoring land usage like the centuries-old pastures of the Bedouin population. ${ }^{40}$ The parodic nature of Alÿs's The Green Line, which accentuates the fact that this highly influential boundary is in fact relatively unrecognizable on the actual ground, gives viewers the sense that the work first and foremost demonstrates the artificiality and absurdity of the Green Line, and perhaps even of borders in general. Indeed, one of the themes that returns in various episodes of Alÿs's narrative is the idea that all order and divisions, for instance in the form of borders, are enforced onto a changeable and continuous world.

The absurdity and artificiality of border politics is perhaps most saliently revealed in The Loop (1997), in which Alÿs took one month and five days to travel from Tijuana, Mexico, to San Diego, crossing through Central and South America, the Pacific Rim, China, Russia, Canada, and the United States. Avoiding the border between Mexico and the United States, the artist not only reversed the modern ideal of minimum effort, maximum result (for Alÿs an earmark of economic logic), but also mockingly contrasted the obstacles migrant workers face when attempting to cross borders to the unreflective ease and naturalness with which artists and other art world denizens nowadays travel the world from one biennial or triennial to another. ${ }^{41}$ With regard to a later work, Don't Cross the Bridge Before You Get to the River (working title) (2008), Alÿs has said that the 'contradiction of our times' is: 'how can we live in a global economy and be refused free global flow?'42 For this work, Alÿs instructed one line of children with toy boats in the Strait of Gibraltar to leave Spain in the direction of Morocco and another one to wade towards Spain from Morocco, with the imaginary intention of meeting at the horizon. Both of these works resist the stagnation of flow and continuity, caused by the economic system, political control, and fear of 'other' people, like the illegal immigrants who risk their lives in attempts to cross the Us-Mexican border and the Strait of Gibraltar. In all cases the stagnation is the result of the enforcement of unnatural, restricting boundaries onto a changeable, flowing world.

In a different yet comparable way, The Green Line, as mentioned earlier, brings to mind the blatant fact that, when Dayan drew the Green Line on the map (an abstracted representation removed from reality), he did not reckon with the neighborhoods and the free movement of the communities through which the line would cut, indifferent to the social and geographical reality of 1948. It could be argued that this move was concomitant with the way the new

\footnotetext{
$40 \quad$ Newman 1995, p. 8.

41 See: Francis Alÿs, A Story of Deception 2010, pp. 86-87.

42 Francis Alÿs, A Story of Deception 2010, pp. 36, 166-67.
} 
state of Israel had been formed in the late 1940s and 1950s: a 'fictitious undertaking', as Zvi Efrat has argued, of politicians, planners, and architects ignoring existing buildings, infrastructure and people while configuring the land as if it had been vacant and 'amorphous' before. This abstract, two-dimensional 'cardboard proto-state' of the master planners - really an act of power - was constructed, one could state, with disregard of the three-dimensional lived reality, highlighting its artificiality. As Weizman points out in a text on Alÿs's The Green Line, maps manage, regulate, and order the world 'as much as they represent it'. ${ }^{43}$ He has observed that ' $[\mathrm{t}]$ o drip paint over the surface of the city along [the green] line is to transform, for the duration of this walk, the territory into a map, a one-to-one map. ${ }^{44}$ This mapping of a paper map on the surface of the real city, with its 'changes in materiality, patterns of light and shadow [...], textures of the ground, as well as its social reality, drives home the distance between the conceptual space in which political decisions are made and the experiential space onto which these decisions are imposed. ${ }^{45}$

Weizman argues that the power of Alÿs's retracing of the Green Line is that it provides a provocative 'challenge to the existing dominant and expansionist logic of the city', but claims that The Green Line fails to question 'the very logic of separation'. Weizman himself believes that the seed of a peaceful future does not lie in yet 'another borderline', but in 'the possible emergence of a shared surface'. ${ }^{46}$ The Green Line may, however, as well be read as a questioning of the logic of partition. If the humorous dimension and seeming purposelessness of Alÿs's action are acknowledged, The Green Line can be seen as an attempt to make people aware of the absurdity and impact of the Green Line and of borders in general, an awareness that may have more potential to lead to change than the more commonsense and less extraordinary attempts of politicians. In 2005 and 2007, the following text by Alÿs was written on a wall at the entrance of the aforementioned exhibitions at the Israel Museum and David Zwirner:

Can an artistic intervention truly bring about an unforeseen way of thinking, or is it more a matter of creating a sensation of 'meaninglessness' that shows the absurdity of the situation? Can an absurd act provoke a transgression that makes you abandon the standard assumptions on the sources of conflict? Can those kinds of artistic acts bring about the

\footnotetext{
43 Francis Alÿs, A Story of Deception 2010, p. 176.

44 Francis Alÿs, A Story of Deception 2010, p. 175.

45 Francis Alÿs, A Story of Deception 2010, p. 175.

46 Francis Alÿs, A Story of Deception 2010, p. 177.
} 
possibility of change? In any case, how can art remain politically significant without assuming a doctrinal standpoint or aspiring to become social activism? For the moment, I am exploring the following axiom: Sometimes doing something poetic can become political and sometimes doing something political can become poetic. ${ }^{47}$

Perhaps an artwork that would have staged more ideal circumstances, a vision of a future of peaceful coexistence, would have been more to Weizman's satisfaction, as it would have gone beyond what could be seen as not much more than the rearticulation of a boundary. In various other works, Alÿs does present a vision of a less partitioned, superior world, if in a highly imaginary, unpractical way. In his work in the Strait of Gibraltar, the two lines of Moroccans and Spaniards evoke the image of a meeting at the horizon, envisaging a more desirable situation with fewer restrictions and obstructions. This 2008 work clearly revisits an earlier work, Bridge/Puente (2006), for which Alÿs requested fishermen in both Havana and Key West to position their boats in lines pointing toward the city on the opposite side of the Straits of Florida, generating the fabular mental image of a collective effort creating a 'floating bridge' between the United States and Cuba, two nations in conflict. ${ }^{48}$ But whereas such works use the strategy of imagination, The Green Line refers to the actual past, relating it to the actual present.

It seems precisely the sense of purposelessness and the manifestation of the absurdity of past events and the current, very real situation, along with the absence of a proposal that suggests a way out of deadlock, that prevents The Green Line from becoming one-dimensionally doctrinal and activist, or naively optimistic. Given the close to unsurpassable complexity of the Israeli-Palestine conflict, Alÿs was not really in the position to envisage a mythical, unified, non-partitioned space for Jerusalem in the vein of Bridge/Puente, one that might have embodied the hope Alÿs has frequently expressed that rumors set off by his works could lead to a transformation of fiction into reality. ${ }^{49}$ The potential of rumors triggered by The Green Line to bring about change are more likely to reside in the work's invitation to viewers to see the actual situation as absurd. The ludicrous transgression of most of Alÿs's actions, including The Green Line but also When Faith Moves Mountains (2002), for which 500 volunteers moved an enormous sand dune near Lima, Peru, ten centimeters from its

\footnotetext{
$47 \quad$ Francis Alÿs 2007, s.p.

48 See: Medina et al. 2007, pp. 104-07; Francis Alÿs, A Story of Deception 2010, pp. 158-59.

49 For a discussion of Alÿs's notion of the transformational, circulatory power of rumor, see: Francis Alÿs, A Story of Deception 2010, pp. 41, 89; Seven Walks 2005, p. 24.
} 
original place, makes the works memorable and especially suitable subjects of rumors. The use of humor not only allows artists to confront people with sensitive situations, affronting them with painful issues from a humorous distance $^{50}$ : unexpected absurdities are also more likely to stick to people's memories and become material for discussion, especially if the event to be remembered can be condensed into a concise image or anecdote, as is usually the case with Alÿs's projects, which often translate socio-political tensions into a simple visual-spatial form, like a line. Mark Godfrey has elaborately discussed Alÿs's strategy of devising performances that can easily be distilled into a single, succinct image, phrase, or aphorism, one that can crystalize the entire work. ${ }^{51}$ This condensation facilitates the subsequent dissemination of the work to a vast public, beyond the art community, through postcards, DVD's, magazines, websites, and - most importantly - rumors. ${ }^{52}$ It is in this democratic post-stage of his works, in which rumors are spread by mouth, published texts, or mediums such as the internet, that Alyss situates the power of the work to bring about the promise of change, to 'affect the social imaginary', 53 to cause people to 'revise' their own 'discourse'. ${ }^{54}$ The absurdity of a work, in addition to the work's capacity to cause a 'clash' between the artist's concerns and the local situation into which the work intervenes, is likely to increase the power of art to provoke change, as it offers a 'moment of suspension of meaning, a brief sensation of senselessness that reveals the absurdity of the situation and, through this act of transgression', which makes people 'step back or step out', it can 'open up - even if just for a few seconds - a new, other, perspective on the situation. ${ }^{55}$ It is through this strategy of absurdity that 'sometimes doing something poetic can become political'.

50 For remarks of Alÿs's on the critical power of humor, which 'often allows you to bypass situations that would not otherwise have been allowed to happen if I had, for instance, a militant attitude', see: 'Walking the Line' 2009, p. 4 and Russell Ferguson, 'Interview', in Francis Alÿs 2007, p. 25 .

$5^{1} \quad$ Godfrey in: Francis Alÿs, A Story of Deception 2010, p. 10.

$5^{2} \quad$ Francis Alÿs, A Story of Deception 2010, pp. 15, 127.

53 Francis Alÿs, A Story of Deception 2010, p. 51.

54 Alÿs and Medina 2005, p. 9o. It is partly because of the emphasis Alÿs places on the power of dissemination that materials like letters, notes, and sketches are exhibited along with documentation of the artist's performances: these materials all add more dimensions to the discourse and rumors prompted by the artwork.

55 Russell Ferguson, 'Interview', in: Francis Alÿs 2007, p. 40. 


\section{Resolving Dialectical Structures: A Practice of Disruption}

As suggested earlier in this essay, Alÿs's works often combine seemingly opposite concepts, practices, and terms, dissolving the dichotomy in the process. The works may incorporate both simplicity and complexity, inflexibility and transience, conflict and resolution, humor and seriousness, the local and the global, art and life, and poetry and politics. This dialectical structure already appeared in some of Alÿs's earliest works. The Collector (1990-92), for instance, featured the artist walking through Mexico City with a tiny magnetic dog on wheels that collected the metallic waste it encountered in the streets. Hinting at street dogs and people surviving on the garbage found on the streets, realities that Alÿs credited with the power to resist the regulated, hygienic modern ideal of urban planning, The Collector not only prefigured the later works' criticism of the modern Western ideal of control and regulation, but also the dialectical play that characterizes much of the later work. The Collector's dialectics moved between the positive and negative magnetic poles, art and non-art (the daily life of garbage), and serious social commentary on the one hand and humorous, childlike play on the other. ${ }^{56}$

Another early work, Bridge (Snails) (1992), features combinations of opposites that are even more clearly related to The Green Line (Fig. 2.5). In an exhibition space in Brussels, Alÿs released 1300 snails on the walls and ceiling. The snails tended to stay within a linear perimeter of green soap with a width of 8 centimeters and a length of 112 meters, consuming the drawings hanging on the wall within the green line, which they were unable to cross. Alÿs has commented that the line of soap turns into the hygienic filter separating and protecting the artwork from the public and vice-versa, while a play of territories takes place in between the floor occupied by the visitors and the walls and ceiling invaded by the snails. ${ }^{57}$ While the green line segregated the animals from the humans, protecting the visitors from the snails, there was one passage in the otherwise impervious boundary line: a soapless column in the middle of the gallery connecting the territory of the snails, which included the ceiling, to that of the visitors, who stood on the floor. Alÿs and art critic Cuauhtémoc Medina have written that, although the 'segregation and communication between both spaces suggested the fantasy of their unification', 'even that utopian possibility was disturbing': 'Not far away was the memory of the disruption of civilized order by an invasion of animals'.58 Bridge (Snails) is clearly related

\footnotetext{
56 Francis Alÿs, A Story of Deception 2010, pp. 50-51.

57 Francis Alÿs, A Story of Deception 2010, pp. 54-55.

$5^{8}$ Francis Alÿs, A Story of Deception 2010, pp. 54-55.
} 


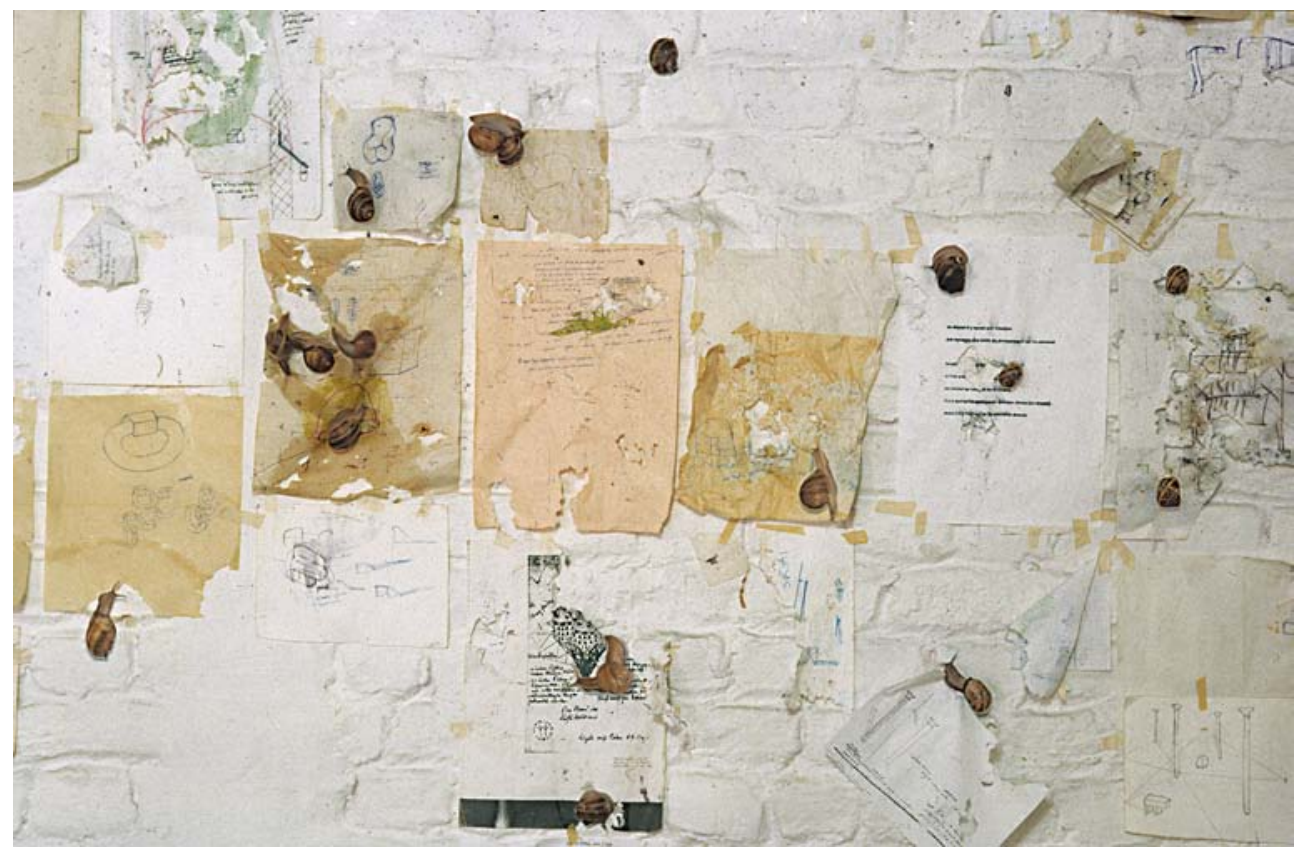

FIGURE 2.5

Francis Alÿs, Bridge (Snails), Brussels 1992, Installation. РHOTO: FRANCIS ALŸs. COURTESY DAVID ZWIRNER, NEW YORK/LONDON.

to the artist's exploration during his architectural training of the transformation in the late Middle Ages to a new, modern model of city planning, in which animals no longer co-existed with people near the old city center, but were evicted to land outside of the city walls, a transformation the artist obviously laments. ${ }^{59}$ The utopian possibility Alÿs and Medina recognized in Bridge (Snails) consisted in the promise of disruption of this modern, civilized organization of urban space.

The question arises of whether Alÿs with The Green Line, which seems to refer in various ways to the earlier Bridge (Snails), also hoped to give a glimpse of the utopian possibility of unification and co-existence, though The Green Line did not feature a bridge for Palestians or Israeli that could have served a function comparable to that of the column in Bridge (Snails). It is not irrelevant to note in this context that in some of Alÿs's works, lines do not separate but connect, as is very literally depicted in the painting Snakes and Ladders (2008), undoubtedly related to his work in the Strait of Gibraltar of the same year (Fig. 2.6). In this small painting, the green snake and ladder, instead of 


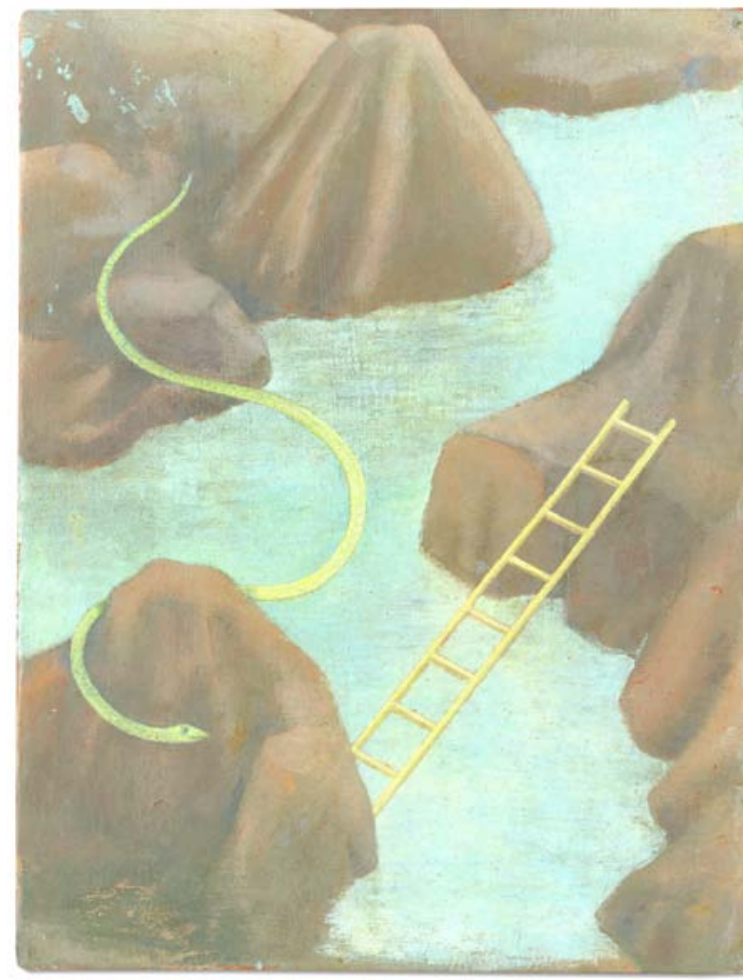

FIGURE 2.6 Francis Alÿs, Snakes and Ladders, 20o8, oil and encaustic on canvas, $28.7 \times 22 \mathrm{~cm}$. COURTESY DAVID ZWIRNER, NEW YORK/ LONDON.

connecting board squares as in the homonymous game, link mountains that are separated by water. But where lines in the guise of bridges - as well as in the form of corridors of cooperating people (Don't Cross the Bridge Before You Get to the River, Bridge/Puente, and When Faith Moves Mountains) - can bring together, when given the function of boundary, they tend to separate. If Alÿs's line in The Green Line has a utopian possibility, besides its potential to revise people's perspectives through absurdity, it may instead lie, as suggested before, in the fact that it is less transient than the walls that were being built around 2004. The transience of the line might suggest that segregating lines are acceptable to Alÿs as long as they are flexible and provisional.

If Bridge (Snails) simultaneously brings to light and questions the validity of lines of demarcation between animals and humans, the uncivilized and the civilized, revulsion and attraction, public and private, life and art, and division and unification, it is not only the last pair that 12 years later again took on a 
primary role in The Green Line, but certainly also the second to last pair: the life-art dichotomy. Where Bridge (Snails) brings elements of life, or nature, to an art context, The Green Line most obviously brings art to life, revisiting Alÿs's less politically-charged action The Leak (1995), in which the artist left a gallery with a perforated can of paint, walked through the neighborhood and returned to the gallery after having found his way back to the gallery with the aid of the paint trail. ${ }^{60}$ The Leak obviously alludes to Jackson Pollock's action painting and dripping technique, although Alÿs replaced the arena of the canvas by that of the urban surface, taking art beyond the confining white architectonic cube of the gallery.

Alÿs has disclosed that with The Leak, he hoped to 'create a narrative produced by a material expenditure or dissipation', generating a story by using up material paint, perhaps in reference to the dematerialization of art since the 1960s, but more pertinently relating to his decision as an artist and former-architect not to make buildings, sculpture or other objects, all of which have a certain 'consistency'. ${ }^{61}$ Through the practice of walking, an 'exercise with a temporality akin to that of narrative', as opposed to the stability of objects, Alÿs rather wanted to challenge the 'permanence' of art. ${ }^{62}$ The temporality of everyday life, walking, and narrative as such offers Alÿs a mode of resistance within the field of art. With his ambulatory explorations of the poetic potential of unplanned events and situations in the urban fabric, he moreover attempted to resist the prevailing concept of architecture and urbanism as 'a predetermined field of trajectories and transactions'. ${ }^{63}$ As walking is marked by temporality and movement, and cannot be controlled and predetermined, it can challenge the modern systems of control and regulation that have come to dominate our lives, including those that have enforced artificial political borders. ${ }^{64}$ During walks, our direct contact with our concrete environment leads us to experience the unexpected, undetermined, and inconsistent, which provides us with a mode to escape from the structures that attempt to order, divide, and control everything.

Alÿs has compared The Leak's 'material expenditure' to that of his performance Fairy Tales of the same year, a walk through Mexico City (re-enacted in Stockholm in 1998) during which he left behind a trail by unraveling his own sweater, as if unweaving the 'thread' of a narrative that had previously been

\footnotetext{
6o Alÿs performed The Leak both in São Paulo and in Ghent in 1995 .

$61 \quad$ Francis Alÿs, A Story of Deception 2010, p. 66.

62 Francis Alÿs, A Story of Deception 2010, pp. 47- 49.

63 Francis Alÿs, A Story of Deception 2010, p. 47.

64 Francis Alÿs, A Story of Deception 2010, pp. 47-52.
} 
woven. ${ }^{65}$ Like The Leak and The Green Line, Fairy Tales is an act of 'productive unmaking akin to the unravelling of tales and stories'.66 The references to the fairy tale of Hansel and Gretel, the myth of Ariadne, Theseus, and the Minotaur's labyrinth, as well as the story of Penelope's nightly undoing of the shroud she weaves during the day are most explicit in Fairy Tales, but can also be related to The Leak and The Green Line. ${ }^{67}$ Also applicable to The Green Line is Alÿs's comment on the fabular dimension of Fairy Tales: 'Whereas the highly rational societies of the Renaissance felt the need to create utopias, we in our times must create fables' ${ }^{68}$ Unweaving within the everyday reality of Jerusalem a thread of paint that originated both in the story of art and in the history of that holy yet conflicted city can be seen as parallel also to another work that Alÿs has associated with fables: When Faith Moves Mountains. Like this earlier work, which took place in a transitional, post-dictatorial period during which Peru was struggling to institute a democracy, The Green Line attempted to 'translate social tensions into narratives' and 'visual-spatial form', with the intent to 'infiltrate the local history and mythology' of Jerusalem, 'to insert another rumor into its narrative' in the hope that the action would become a story, a fable, that will 'survive the event itself', intervening in the 'imaginal landscape' of the city, and thereby 'actualizing' the work. ${ }^{69}$

Of all his numerous performances, The Leak must have seemed to Alÿs to offer most unexplored possibilities, as it is the only work to which he returned several times. A year before his walk through Jerusalem, Alÿs had walked with a pierced can of blue paint from the Musée d'Art Moderne de la Ville de Paris to a former convent in the Latin Quarter to which the museum located temporarily while its permanent building was being renovated. Alÿs and Medina have written that the artist reenacted The Leak multiple times because it is a 'paradigm' of the artist's 'desire to leave a permanent trace in the fabric of the city and the collective imagination of its inhabitants through the act of walking', suggesting that it on the one hand mocked artists' narcissistic eagerness to leave a permanent trace of themselves in the world while on the other hand expressing the more altruistic ambition of affecting the world in a positive manner through this trace. ${ }^{70}$ Alÿs and Medina have indicated that with such

\footnotetext{
65 Francis Alÿs, A Story of Deception 2010, p. 90.

66 Francis Alÿs, A Story of Deception 2010, pp. 66-67.

67 Francis Alÿs, A Story of Deception 2010, p. 90.

68 Francis Alÿs, A Story of Deception 2010, p. 90.

69 These words of Alÿs's describe When Faith Moves Mountains. Alÿs and Anton 2002, p. 147; Francis Alÿs, A Story of Deception 2010, pp. 15, 36, 126-29. 
actions involving dispelling and the leaving of a trace, the artist reversed the principle of earlier works like The Collector, which was a gathering (of non-art into the realm of art) rather than a marking (of a non-artistic site through an artistic act). ${ }^{71}$ In these works, one might say, Alÿs explicitly acted out his insight that ' $[. .$.$] any art document is, by nature, a self-conscious intervention in the$ complex texture of reality - at least in terms of provoking a hiatus in the customary order of things'. ${ }^{72}$ Alÿs's axiom 'sometimes doing something poetic can become political', part of the subtitle of The Green Line, takes this statement into the realm of the political.

The dictum 'sometimes doing something poetic can become political', which expresses Alÿs's desire that art can affect life on a political level, is in turn related to the artist's much-quoted proposition 'Sometimes doing nothing leads to something', a principle that reverses the proposition 'Sometimes doing something leads to nothing', which is also the subtitle of the five-minute video Paradox of Praxis 1 (1997). This video documents Alÿs pushing a big block of ice through the streets of Mexico City until it is no more than a puddle of water. Another instance of productive unmaking, Paradox of Praxis 1 is a parody of the 'unproductive hardship involved in the daily survival tactics' of many laboring people in Latin America, playing out the disproportionate relation between maximum effort and minimum outcome. It is one of a number of artworks in which Alÿs comments on the battle of Latin American countries to 'adjust to the social and economic expectations of their northern neighbors' in an 'epic of effort'. ${ }^{73}$ Besides a commentary on the local, or in this case regional, situation, Paradox of Praxis 1 also explores the question of whether art can lead to true change or whether art really is without purpose, a question also broached in When Faith Moves Mountains, which carried the motto 'maximum effort, minimum result', inverting 'the principle of efficiency that lies at the heart of modern economic thought' but also provoking reflection on the purposes of art. ${ }^{74}$ It is not a coincidence that the axiom 'Sometimes doing something leads to nothing, and sometimes doing nothing leads to something' has a structure analogous to 'Sometimes doing something poetic can become political, and sometimes doing something political can become poetic'. Where the poetic and art tend to be associated with the 'nothing' and the purposelessness, the political is more likely to be connected to the 'something' and the

\footnotetext{
$71 \quad$ Francis Alÿs, A Story of Deception 2010, p. 90.

$72 \quad$ Francis Alÿs, A Story of Deception 2010, p. 76.

73 From a description by Alÿs and Medina of Rehearsal I (1999-2000), in which a car fails to ascend a hill in Tijuana. Francis Alÿs, A Story of Deception 2010, pp. 102-3.

$74 \quad$ Francis Alÿs, A Story of Deception 2010, p. 127.
} 
'purposeful'. In his action Turista of 1994, in which Alÿs stood in line with unemployed Mexican laborers offering his 'services' as a tourist, he seemed to ridicule the purposelessness of artist's work. Standing behind a sign identifying him as 'Turista', the artist empathized with the laborers' struggle to survive in a capitalist economy but also self-mockingly identified the role of the artist as 'professional observer'. 75

Alÿs has stated that for more than 10 years after his exploration of the adage 'sometimes doing something leads to nothing', he attempted to devise a sequel with actions that were to 'illustrate the contrary principle: 'sometimes doing

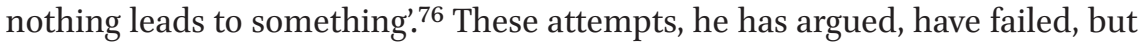
the failure has inspired 'a number of other works based on the questioning of efficiency'. The Green Line seems to simultaneously question the capacity of art to lead to true political change and cautiously express the belief that art, possibly through its absurdity, can be qualified to 'provoke a hiatus in the customary order of things' and lead to different perspectives, more, at least, than the extremely time-consuming, expensive political negotiations and military efforts that have offered no way out of the conflict up until now. ${ }^{77}$ Even if it may not explore concepts like 'faith', bridge', and change' in as courageously and 'naively utopian' a way as When Faith Moves Mountains, The Green Line is still relatively optimistic and resistant in that it is unwilling to conform to the 'climate of skepticism' that doubts all ambitious attempts at provoking political change. ${ }^{78}$ Even if The Green Line does not offer as tangible a utopian possibility as Bridge (Snails), which invites viewers to imagine a unification between animals and humans, like that earlier work it incites a disruption by, on the one hand, revealing the tendency of human beings to bring about segregation through lines of demarcation and, on the other hand, concurrently incorporating ingredients than can counter separating forces, such as the point of potential passage in Bridge (Snails), but also the transience and non-intrusiveness of the painted line in The Green Line. It contains the hope that art can make a difference, leading people to think differently through the strategy of the absurdity.

Alÿs has explained that he does not want to 'add to the city', but 'to absorb what was already there, to work with the residues, or with the negative spaces, the holes, the spaces in-between.79 It is the negative spaces in the

\footnotetext{
75 Francis Alÿs, A Story of Deception 2010, p. 61

76 Francis Alÿs, A Story of Deception 2010, p. 82

77 Francis Alÿs, A Story of Deception 2010, p. 76

78 Russell Ferguson, 'Interview', in: Francis Alÿs 2007, p. 48.

79 Alÿs in: Seven Walks 2005, p. 44.
} 
modern hegemonic structures, including perhaps semi-forgotten yet fully present borders, that have the power to disrupt and resist these structures. The structure of Alÿs's narrative, like the structure of its particular episodes like The Green Line, seems to oscillate between opposites: a negation of opposites through an exploration of liminal, interstitial spaces, spaces in-between, a structure that seems to resonate in the artist's exploration of both the futility and potency of art as well as in his desire to invite people to reflect on solutions to conflicts while simultaneously drawing inspiration from them, seemingly conceiving of conflicts as instigators of change. ${ }^{80}$ It is in the places inbetween, where dichotomies come together, that the order of things can be resisted.

\section{Bibliography}

Against the Wall. Marlene Dumas, exhib. cat., New York: David Zwirner Gallery 2010.

“'Against the Wall” by Marlene Dumas opens at Serralves Museum', Artdaily.org (July 2, 2010), http://artdaily.com/news/39009/-Against-the-Wall--by-Marlene-DumasOpens-at-Serralves-Museum\#.UsQMQPTuI6g (accessed October 2013).

Alÿs, Francis and Saul Anton, 'A Thousand Words: Francis Alÿs talks about When Faith Moves Mountains', Artforum 10, no. 40 (Summer 2002), pp. 146-47.

Alÿs, Francis and Cuauhtémoc Medina, When Faith Moves Mountains, Madrid 2005.

Alÿs, Francis, Sometimes doing something poetic can become political, and sometimes doing something political can become poetic, exhib. cat., New York: David Zwirner Gallery 2007.

Alÿs, Francis, and Jef Lambrechts, 'The Canvas - Interview with Francis Alÿs: “The Observer Position is the Point of View of an Outsider"', $<H>$ art International, no. 118 (7 November 2013), http://www.kunsthart.org/fr/16/51/the-canvas-interview-withfrancis-Alÿs-the-observer-position-is-the-point-of-view-of-an-outsider-.aspx (accessed November 2013).

Art|4o|Basel. David Zwirner, New York: David Zwirner Gallery 2009.

Benvenisti, Meron, City of Stone. The Hidden History of Jerusalem, Berkeley and Los Angeles 1996.

Fabiola. An Investigation, exhib. cat., ed. by Lynne Cooke and Karen Kelly, New York: Dia Art Foundation 2008.

Francis Alÿs, A Story of Deception, exhib. cat., ed. by Mark Godfrey, Klaus Biesenbach, and Kerryn Greenberg, New York: The Museum of Modern Art 2010.

$80 \quad$ Francis Alÿs and James Lingwood, 'Rumours: A conversation between Francis Alÿs and James Lingwood', in: Alÿs and Medina 2005, p. 44. 
Hanson Bourke, Dale, The Israeli-Palestinian Conflict. Tough Questions, Direct Answers, Downers Grove, IL 2013.

Medina, Cuauhtémoc, Russel Ferguson, and Jean Fisher, Francis Alÿs, London and New York 2007.

Newman, David, Boundaries in Flux: The 'Green Line' Boundary between Israel and the West Bank. Past, Present and Future, Boundary \& Territory Briefing 1 no. 7 , ed. by Clive Schofield, Durham 1995 .

The Object Quality of the Problem (on the Space of Palestine/ Israel), exhib. cat., ed. by Katrina Brown and Penelope Curtis, Leeds: The Henry Moore Institute 2008.

O'Rourke, Karen, Walking and Mapping. Artists as Cartographers, Cambridge MA 2013. Seven Walks, exhib. cat., ed. by James Lingwood, London: Artangel and National Portrait Gallery 2005.

'Walking the Line: Francis Alÿs interviewed by Anna Dezeuze', Art Monthly, no. 323 (February 2009), pp. 1-6.

Weizman, Eyal, Hollow Land. Israel's Architecture of Occupation, London and New York 2007 . 